\title{
Plagiorhynchidae (Acanthocephala) including the description of a new species from birds from the Republic of the Côte d'Ivoire, Africa
}

\section{Lesley R. SMALES}

Parasitology Section, South Australian Museum, North terrace Adelaide 5000 South Australia, Australia.Email: 1.warner@cqu.edu.au

\begin{abstract}
Plagiorhynchidae (Acanthocephala) including the description of a new species from birds from the Côte d'Ivoire, Africa. - Plagiorhynchidae including Porrorchis centropi (Porta, 1910), from Centropus senegalensis and C. leucogaster, a putative Lueheia species from Halcyon malimbica and Bubulcus ibis are reported from the Republic of Côte d'Ivoire for the first time. Plagiorhynchus (Prosthorhynchus) cossyphicola sp. n. from Cossypha spp. is distinguished from congenerics by a combination of the size of the proboscis and its armature.
\end{abstract}

Keywords: Parasite - Acanthocephala - Plagiorhynchus - Porrorchis Lueheia - Africa - Côte d'Ivoire - Centropus - Cossypha - Halcyon Bubulcus.

\section{INTRODUCTION}

The Acanthocephala from African birds are not well known, only a small number of reports, mostly focusing on domestic species of poultry and guinea fowl, having been published. Of the Plagiorhynchidae, only species of the genera Plagiorhynchus Luhe, 1911, Porrorchis Fukui, 1929, and Pseudogordiorhynchus Golvan, 1957 have been reported from African birds; Porrorchis centropi (Porta, 1910) from Guinea Bissau and Senegal, West Africa, Po. Indicus (Das, 1957) from Egypt, Po. rotundatus (Linstow, 1897) and Po. maxvachoni (Golvan \& Brygoo, 1965) from Madagascar, Plagiorhynchus cylindraceus (Goeze, 1782) from South Africa, Pl. charadriicola (Dollfus, 1953) from North Africa and Pseudogordiorhynchus antonmeyeri Golvan, 1957 from West Africa (Ashmawy \& El-Sokkary, 1991; Amin et al., 1999; Golvan, 1956a, b, c, 1957, 1958; Golvan \& Brygoo, 1965; Vassiliadès, 1980). To the best of my knowledge there have, however, been no reports of acanthocephalans from birds from the Republic of Côte d'Ivoire.

Between 1985 and 1988, during the course of a Ph D project of Dr J. Mariaux to study the cestode parasites of the birds of the Republic of Côte d'Ivoire, an incidental collection of Acanthocephala from 22 species representing 15 families of birds was made. Within this collection six bird species were infected with three species of plagiorhynchid acanthocephalans, as reported below. In this paper new host records are documented, geographic locations given, including the significance of the finding of a species similar to a Lueheia sp. and a new species of Plagiorhynchus is described.

Manuscript accepted 27.11.2009 


\section{MATERIALS AND METHODS}

The birds examined included 24 individuals of 7 species from 4 families. The collection localities of hosts from which plagiorhynchids were dissected, with the number of infected hosts in parentheses were as follows:

Halcyon malimbica (Shaw, 1811) from M'be/Koffidougou $7^{\circ} 44^{\prime} \mathrm{N} 4^{\circ} 20^{\prime} \mathrm{W}$ (1), Halcyon senegalensis (Lesson, 1766) Marais de Dabou 5¹9'N 4¹9'W (1)

Bubulcus ibis (Linnaeus, 1758) from Adiopodoume $5^{\circ} 19^{\prime} \mathrm{N} 4^{\circ} 08^{\prime} \mathrm{W}(1)$;

Centropus leucogaster (Leach, 1814) from M'be/Koffidougou $7^{\circ} 44^{\prime} \mathrm{N} 4^{\circ} 20^{\prime} \mathrm{W}$ (1);

Centropus senegalensis Linneaus, 1766 from Adiopodoume $5^{\circ} 19^{\prime} \mathrm{N} 4^{\circ} 08^{\prime} \mathrm{W}(2)$; Cossypha niveicapilla (Lafresnaye, 1838) from Ouango-Fitini $9^{\circ} 37^{\prime} \mathrm{N} 4^{\circ} 03^{\prime} \mathrm{W}$ (1);

Cossypha albicapilla (Vieillot, 1818) from Korhogo $9^{\circ} 27^{\prime} \mathrm{N} 5^{\circ} 31^{\prime} \mathrm{W}$ (1).

On dissection all specimens were fixed with neutral buffered $4 \%$ formalin and stored in $75 \%$ ethanol. Before microscopic examination all specimens were cleared in lactophenol or beechwood creosote to be studied as wet mounts. All measurements were taken using an eyepiece micrometer and are given in micrometers unless otherwise stated. Figures were drawn with the aid of a drawing tube.

All specimens collected for this study are registered in the Muséum d'Histoire Naturelle, Geneva, Switzerland (MHNG).

\section{RESULTS}

The three species of plagiorhynchid acanthocephalan found are given in Table 1.

TABLE 1 Acanthocephala from eight bird hosts from the Republic of Côte d'Ivoire, Africa collected between January 1987 and February 1988.

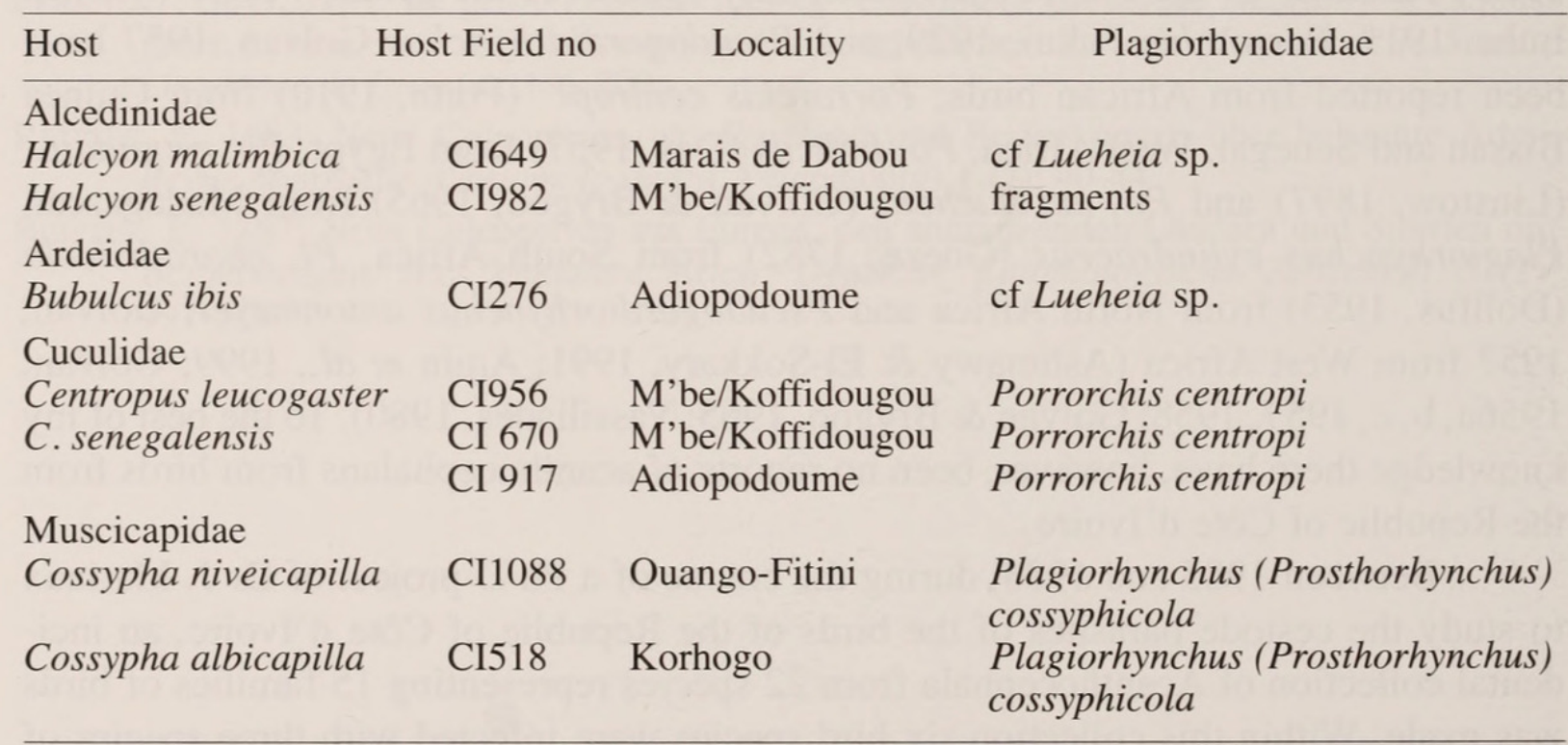

Cystacanths, juveniles and adults of Porrorchis centropi (MHNG INVE 38497, INVE 38493, INVE 38495) occurred in both species of Centropus; prevalence $100 \%$. These represent a new host record for $C$. leucogaster and new locality records for both host species. 
Cystacanths of a porrorchid (MHNG INVE 38480, INVE 38492) with a sub globular to claviform proboscis having an armature of 26-28 rows of 9-10 hooks and at least 4 tubular lemnisci occurred in Bubulcus ibis, prevalence 10\% and Halcyon malimbica, prevalence $20 \%$. These characters, particularly the multiple lemnisci are congruent with Lueheia spp. This genus has not previously been recorded from Africa.

A fragment of a porrorchid was also found in one individual of $H$. senegalensis, but could not be identified further (MHNG INVE 38597).

\section{Plagiorhynchus (Prosthorhynchus) cossyphicola sp. n.}

Figs 1-6

MATERIAL EXAMINED: Holotype, male, from Cossypha albicapilla (Vieillot, 1818) small intestine: Côte d'Ivoire, Korhogo; 27.01.1987, J. Mariaux (MHNG INVE 38484). - 2 specimens, one male proboscis missing, one female anterior end damaged, from Cossypha niveicapilla (Lafresnaye, 1838), small intestine: Côte d'Ivoire, Ouango-Fitini; 18. ii. 1988, J. Mariaux (MHNG INVE 38506). Prevalence: 33\%.

\section{DESCRIPTION}

GENERAL (based on holotype and voucher specimens): Robust, relatively small, trunk slightly fusiform, unarmed. Proboscis cylindrical, armed with 16 long straight rows of more than 11, possibly up to 13 , hooks, thorns 90-100 long; basal 1-2 hooks of each row shortest, 40-70 long. Roots simple, posteriorly directed, shorter than thorns, basal 1-2 hooks spiniform. Proboscis receptacle double walled, cerebral ganglion at about mid region. Lemnisci slender, tubular, 2200, about twice as long as proboscis receptacle.

MALE: measurements of holotype followed by measurements of voucher specimen when available. Trunk $6,5.3 \mathrm{~mm}$ long, 880,885 wide. Proboscis slightly inverted, about 780 long, 240 wide; neck short, conical, 100 long, 260, 280 wide; proboscis receptacle 1445, 1530 long, 325, 305 wide. Testes tandem, oval, contiguous; anterior testis 510, 730 long, 390, 450 wide; posterior testis 525, 565 long, 415, 435 wide. Cement glands 4, tubular, 1200, 1530 long. Genital pore sub terminal.

FEMALE: based on posterior $3 \mathrm{~mm}$ only. Posterior end of trunk narrows suddenly about 150 from end. Genital apparatus short, robust, with well developed vagina and comparatively large uterine bell, 445 long. Genital pore terminal. Eggs ovoid, 59.562.5 long, 29.5 wide; external shell sculptured with elevated ridges and grooves particularly at the poles, without prolongations of the fertilization membrane.

COMMENTS: Despite only one specimen having an intact, although slightly inverted proboscis, the total length of the proboscis could be calculated by including an estimate of the length of the clearly visible inverted portion within the anterior part of the proboscis (Fig 2). In the key to the species of the subgenus Prosthorhynchus by Amin et al. (1999) Plagiorhynchus (Prosthorhynchus) cossyphicola sp. $n$. with a small proboscis, no longer than 780, and an armature of 16 rows of 12-13 hooks falls closest to $P$. (P.) ogatai (Fukui \& Morisita, 1936), which has a proboscis 640-770 long but an armature of 18 rows of 14-15 hooks. Plagiorhynchus (Prosthorynchus) cossyphicola can be further differentiated from P. ogatai in having the thorns of the longest hooks, up to 100 long compared with 70 for $P$. ogatai. The figure from Fukui \& Morisita (1936, Fig 3) indicates that $P$. ogatai has larger, wider testes, the anterior testis about 

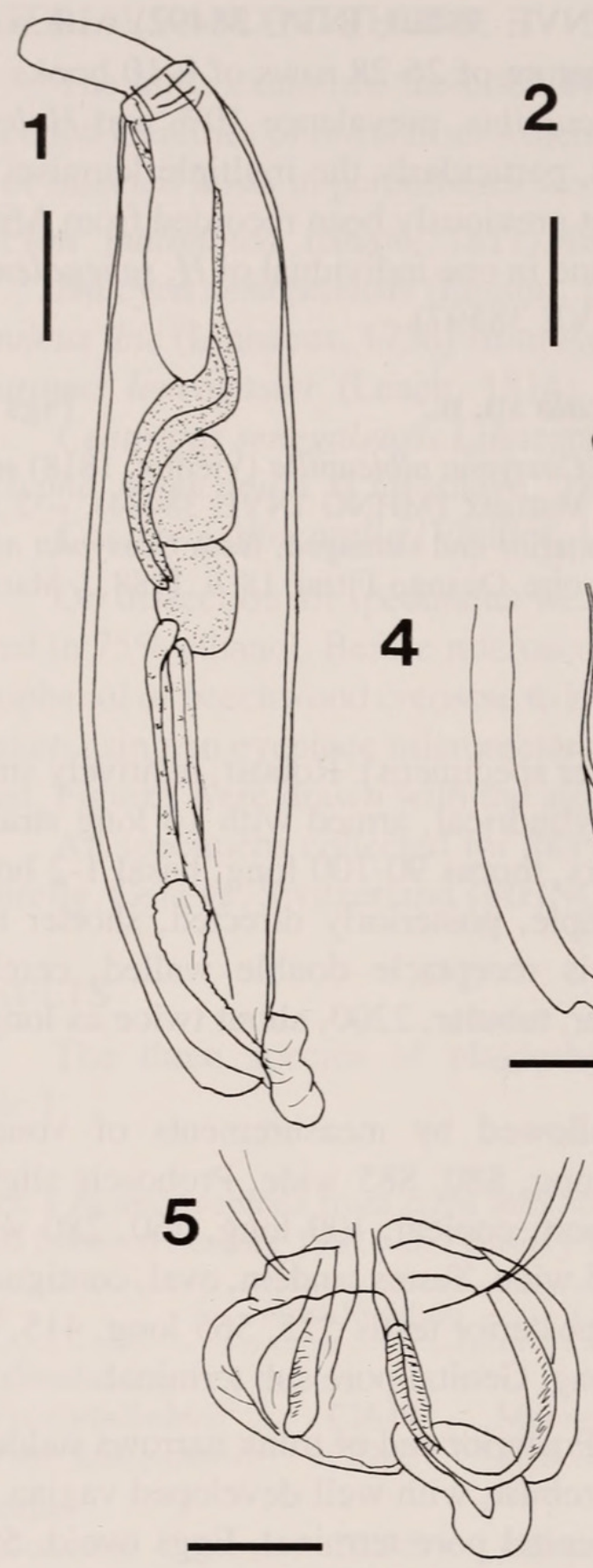
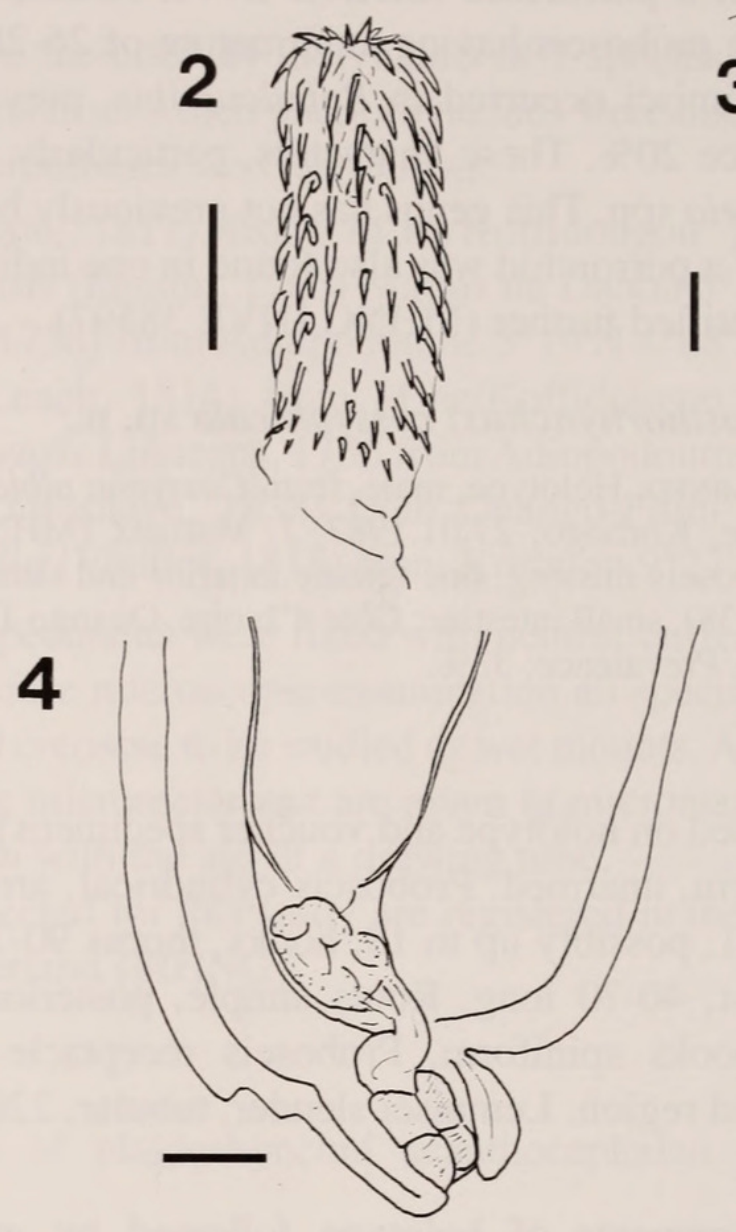
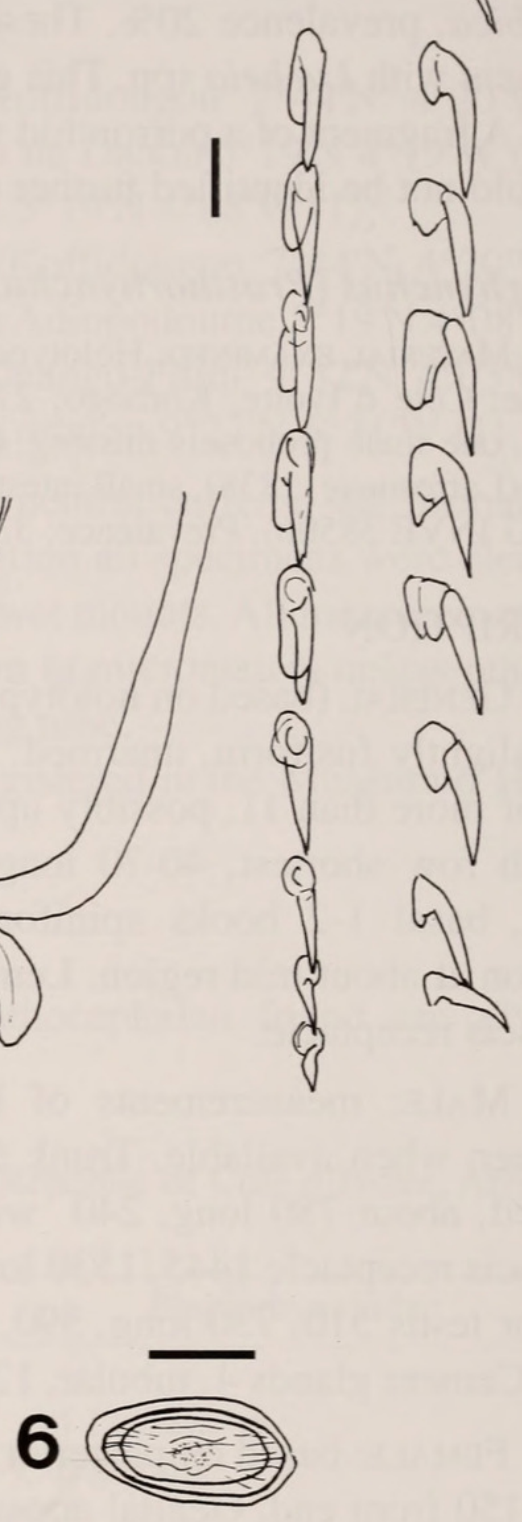

FIGS 1-6

Plagiorhynchus (Prosthorynchus) cossyphicola n. sp. (1) Holotype male. (2) Proboscis showing armature. (3) Proboscis rows of hooks. (4) Female posterior end. (5) Male bursa. (6) Egg. Scale bars: $1,750 \mu \mathrm{m} ; 2,200 \mu \mathrm{m} ; 3,50 \mu \mathrm{m} ; 4,5,100 \mu \mathrm{m} 6,30 \mu \mathrm{m}$.

660 long, 750 wide compared with 510-730 long, 390-430 wide for P. cossyphicola and longer cement glands, about 2700 compared with 1200-1530 long. The eggs of P. cossiphicola, 59.5-62.5 by 29.5 are shorter than those of P. ogatai, 66.67 by 25.53 .

\section{DISCUSSION}

Originally described from C. senegalensis from Guinea Bissau, and redescribed from C. monachus Rüppel, 1837 from Senegal (Golvan, 1956b) the hosts and distribution of Po. centropi have been extended in this study to include another West African country, Côte d'Ivoire and cuculanid host, C. leucogaster. 
Species of the genus Lueheia Travassos, 1919 have been described only from the Americas (Golvan, 1994) and are distinguished from other genera within the Porrorchinae by having multiple lemnisci (Schmidt \& Kuntz, 1967). The cystcanths found in $\mathrm{H}$. malimbica and B. ibis also had multiple lemnisci and are therefore closest to Lueheia and are probably the first representatives of the genus to be identified from Africa. Insufficient morphological information could be gleaned from the cystacanths to unequivocally confirm the genus and to characterize the specimens to species level.

Plagiorhynchus (Pr.) cossyphicola is the second member of the sub genus to be described from Africa, the first being the cosmopolitan species $P$. (Pr.) cylindraceus occurring in South African shore birds (Amin et al., 1999). The only other member of the genus recorded from the continent is P. (Plagiorhynchus) charadriicola (Dollfus, 1953), also from shore birds, but from North Africa (Golvan, 1956a).

\section{ACKNOWLEDGEMENTS}

My thanks to Prof. Mariaux for giving access to the material and providing useful comment on the manuscript.

\section{REFERENCES}

AshMAWY, K. I. \& El-SOKKARY, M. Y. 1991. Morphobiological studies on a Pseudoporrorchis species (Acanthocephala); infecting the Egyptian cuculus (Centropus senegalensis aegyptius). Assiut Veterinary and Medical Journal 25: 98-107.

Amin, O. M., Canaris, A. G. \& Kinsella, J. M. 1999. A taxonomic reconsideration of the Genus Plagiorhynchus s. lat. (Acanthocephalan: Plagiorhynchidae), with descriptions of South African Plagiorhynchus (Prosthorynchus) cylindraceus from shore birds and P. (P.) malayensis, and a key to the species of the subgenus Prosthorynchus. Journal of the Helminthological Society of Washington 66: 123-132.

FukU, T. \& Morisita, T. 1936. Three new species of Acanthocephala from Japan (A. preliminary note) [In Japanese] Dobutsugaku Zasshi 48: 759-764.

Golvan, Y. J. 1956a. Acanthocéphales d'oiseaux. Troisième note. Révision des espèces Européennes de le sous-famille des Plagiorhynchinae A. Meyer 1931 (Polymorphidae) Annales de Parasitologie 31: 350-384.

Golvan, Y. J. 1956b Acanthocéphales d' oiseaux. Quatrième note. Considérations sur le genre Pseudoporrorchis Ch. Joyeux et J.-G. Baer 1935 (Polymorphidae, Porrorchinae) et redescription de Pseudoporrorchis centropi. Bulletin de la Société Zoologique de France 81: 62-71.

Golvan, Y. J. 1956c. Acanthocéphales d'oiseaux. Note additionnelle. Pseudoporrorchis rotundatus (O. von Linstow, 1897) (Palaecanthocephala-Polymorphidae) parasite d'un Cucullidae, Centropus madagascarensis (Briss). Bulletin de la Société Zoologique de France 81: 339-344.

Golvan, Y. J. 1957. Acanthocéphales d'oiseaux. Sixième note. Deux espèces nouvelles parasites d'oiseaux d'Afrique occidentale Française: Gordiorhynchus (Gordiorhynchus) gendrei n. sp. et Pseudogordiorhynchus antnomeyeri n. gen., n. sp. Annales de Parasitologie 32: 81-97.

Golvan, Y. J. 1958. Acanthocéphales d' Afrique occidentale française récoltés par le Dr PierreClaude Morel. Bulletin de l'Institut Français Afrique Noire ser. A 20: 60-72.

Golvan, Y. J. 1994. Nomenclature of the Acanthocephala. Research and Reviews in Parasitology 54: 133-205.

Golvan, Y. J. \& BRYGOO, E.-R. 1965. Acanthocéphales de Madagascar (Deuxième Note) Le genre Pseudoporrorchis Joyeux et Baer 1935. Annales de Parasitologie 40: 543-568. 
Schmidt, G. D. \& Kuntz, R. E. 1967. Revision of the Porrorchinae (Acanthocephala: Plagiorhynchidae) with descriptions of two genera and three new species. Journal of Parasitology 53: 130-141.

VASSILIAdÈs, G. 1980. Helminthes parasites d'oiseaux du Sénégal. Bulletin de l'IFAN 42 sér A 122-134. 


\section{$2 \mathrm{BHL}$ Biodiversity Heritage Library}

Smales, Lesley R. 2010. "Plagiorhynchidae (Acanthocephala) including the description of a new species from birds from the Republic of the Cote d'Ivoire, Africa." Revue suisse de zoologie 117, 153-158.

https://doi.org/10.5962/bhl.part.117596.

View This Item Online: https://www.biodiversitylibrary.org/item/148549

DOI: https://doi.org/10.5962/bhl.part.117596

Permalink: https://www.biodiversitylibrary.org/partpdf/117596

\section{Holding Institution}

American Museum of Natural History Library

\section{Sponsored by}

BHL-SIL-FEDLINK

\section{Copyright \& Reuse}

Copyright Status: In copyright. Digitized with the permission of the rights holder.

Rights Holder: Muséum d'histoire naturelle - Ville de Genève

This document was created from content at the Biodiversity Heritage Library, the world's largest open access digital library for biodiversity literature and archives. Visit BHL at https://www.biodiversitylibrary.org. 